Review

\title{
An Association Map on the Effect of Flavonoids on the Signaling Pathways in Colorectal Cancer
}

\author{
Sanaz Koosha, Mohammed A. Alshawsh ${ }^{\bowtie}$, Chung Yeng Looi, Atefehalsadat Seyedan , Zahurin \\ Mohamed $^{\bowtie}$ \\ Department of Pharmacology, Faculty of Medicine, University of Malaya, 50603 Kuala Lumpur, Malaysia. \\ $\triangle$ Corresponding authors: E-Mail: alshaweshmam@um.edu.my; zahurin@um.edu.my. \\ (C) Ivyspring International Publisher. Reproduction is permitted for personal, noncommercial use, provided that the article is in whole, unmodified, and properly cited. See \\ http://ivyspring.com/terms for terms and conditions.
}

Received: 2015.11.19; Accepted: 2016.03.31; Published: 2016.04.29

\begin{abstract}
Colorectal cancer (CRC) is the third most common type of cancer in the world, causing thousands of deaths annually. Although chemotherapy is known to be an effective treatment to combat colon cancer, it produces severe side effects. Natural products, on the other hand, appear to generate fewer side effects than do chemotherapeutic drugs. Flavonoids are polyphenolic compounds found in various fruits and vegetables known to possess antioxidant activities, and the literature shows that several of these flavonoids have anti-CRC propertiesFlavonoids are classified into five main subclasses: flavonols, flavanones, flavones, flavan-3-ols, and flavanonols. Of these subclasses, the flavanonols have a minimum effect against CRC, whereas the flavones play an important role. The main targets for the inhibitory effect of flavonoids on CRC signaling pathways are caspase; nuclear factor kappa B; mitogen-activated protein kinase/p38; matrix metalloproteinase (MMP)-2, MMP-7, and MMP-9; p53; $\beta$-catenin; cyclin-dependent kinase (CDK)2 and CDK4; and cyclins A, B, D, and E.

In this review article, we summarize the in vitro and in vivo studies that have been performed since 2000 on the anti-CRC properties of flavonoids. We also describe the signaling pathways affected by flavonoids that have been found to be involved in CRC. Some flavonoids have the potential to be an effective alternative to chemotherapeutic drugs in the treatment of colon cancer; well-controlled clinical studies should, however, be conducted to support this proposal.
\end{abstract}

Key words: Colon cancer, Anti-colorectal cancer, Flavonoids, Signaling pathways.

\section{Introduction}

Colon cancer is the third most common type of cancer in the world, with nearly 1.36 million new cases diagnosed in 2012 in both genders [1]. Although cancer of the colon and rectum are more common in developed countries than in developing countries, the mortality rate in developing countries is higher. In 2012, approximately 694,000 deaths were reported from 1.4 million diagnosed cases worldwide [1]. Technological developments in the last few decades have resulted in a sedentary lifestyle, leading to changes in nutrition and exercise [2], which may have contributed to growing cancer rates, including those of colon cancer. The incidence of colon cancer is predicted to increase by $90 \%$ by 2030 [3].

Colorectal cancer $(\mathrm{CRC})$ originates from the epithelial cells lining the colon or rectum in the gastrointestinal tract. Like cells in other types of cancer, colon cancer cells have six common hallmarks: autonomous growth, unresponsiveness to growth-inhibitory signals, evasion of apoptotic signals, unlimited replicative potential, ability to induce angiogenesis needed for expansion and survival of tumors, and migration to other parts of the body.

Although great advancements have been made in the treatment of colon cancer and the control of its progression, there remains much room for improvement. A number of undesired side effects sometimes occur during chemotherapy. Although a myriad of available natural products have shown 
promising anti-cancer properties in vitro and in vivo, only a few plant products are being used for therapeutic purposes in CRC $[4,5]$.

Flavonoids are considered to be the main group of polyphenol compounds for combating colon cancer, more than 5000 of which have been detected for this purpose. Flavonoids comprise five main subclasses: flavonols, flavanones, flavones, flavan-3-ols, and flavanonols [6]. The results of clinical studies investigating the relationship between flavonoid consumption and cancer prevention or development conflict for most types of cancers. Research has shown, however, a relationship between consumption of flavonoids and reduction of CRC risk [6].

In recent years, some studies have been performed to investigate the role of flavonoids in signaling pathways in the treatment of colon cancer. Hence, the objectives of this review are to summarize the findings from articles that have been published since 2000 on the mechanisms of effect of flavonoids on CRC and to describe the different cell signaling mechanisms of cancerous cells affected by flavonoids in vitro and in vivo.

\section{CRC signaling pathways}

The six hallmarks of CRC described earlier appear in several signaling pathways. The most important signaling pathways, however, are mitogen-activated protein kinase (MAPK)/p38, PI3K/Akt, Wnt, and the apoptosis cascades. Flavonoids have been found to affect one or more of these pathways, resulting in the inhibition of CRC.

\section{Flavonoids}

We retrieved all data reported in studies published since 2000 on the role of the main flavonoids (23 flavonoids belonging to five subclasses) in the signaling pathways in CRC. As reported in the literature, flavonoids inhibit cell signaling pathways in various CRC cell lines. Some of these flavonoids also demonstrated significant effects in vivo. The chemical structures of these flavonoids are described in Figure 1, and a summary of the data is presented in Table 1 and Figure 2.

\section{Flavonols}

Flavonols, a group of compounds belonging to the flavonoids that have a 3-hydroxyflavone skeleton, are found in many fruits and vegetables [7]. Some of the compounds in this category, such as quercetin, are known to have anticancer properties [8].

\section{Quercetin}

Quercetin is one of the best known flavonoids. It has been found in onions, tea, apples, cranberries, and beans [9]. As reported in the literature, quercetin has been tested on a wide range of colon cancer cell lines, such as HT-29 (p53 mutant type) [10], HCT-116 (p53 wild type) [11], and SW480 (p53 mutant type) [12]. Quercetin demonstrates antiproliferative activity against CRC by inducing cell cycle arrest in the G2/M phase, cytotoxicity activity, cell differentiation, apoptosis, and attenuation of cell migration [13]. Quercetin reduces cyclin A levels and induces the expression of Cdc-2 and p21 [14]. The chemopreventive activity of quercetin was investigated in vivo on 1, 2-dimethylhydrazineinduced colonic tumorigenesis in rats [15]. According to Park et al. [16], quercetin inhibited the activity of $\beta$-catenin/Tcf in SW480 colon cancer cells. Data confirmed that inhibition of SW480 cells via quercetin is related to the degradation of $\beta$-catenin or downstream compounds and consequently a reduction in the binding of Tcf complexes to DNA. Thus, quercetin leads to the inhibition of the $\beta$-catenin/Tcf signaling pathway.

\section{Kaempferol}

Kaempferol is present in various plants, including tea, strawberries, cranberries, grapefruit, apples, peas, brassicas (broccoli, kale, brussels sprouts, cabbage), chives, spinach, endive, leek, and tomatoes [17, 18]. Kaempferol induces apoptosis in HCT116 CRC cell lines by increasing the expression of p53 upregulated modulator of apoptosis (PUMA). In the DNA damage response, p53 increases the transcription of PUMA and consequently upregulates the translation of PUMA in the cytoplasm. PUMA protein is associated with antiapoptotic factors such as Bcl-x, and the PUMA/Bcl-x complex can cause the release of apoptotic factors such as Bax. The liberated apoptotic factors then activate mitochondria permeability and cytochrome $\mathrm{C}$ release. Kaempferol interferes with the promotion of PUMA, which leads to stimulation of apoptotic cascades [19]. The apoptosis property of kaempferol has also been demonstrated in the HT-29 cell line. HT-29 cells were arrested in $\mathrm{G} 2 / \mathrm{M}$ in the presence of kaempferol. Moreover, kaempferol reduced the expression of cyclin-dependent kinase (CDK)2, CDK4, cyclin D1, cyclin E, and cyclin A [20]. The Akt/extracellular signal-regulated kinase (ERK) pathway was blocked in HT-29 cells in the presence of kaempferol. Insulin-like growth factor (IGF)-1 was also attenuated [21]. From the work by Lee et al., the apoptosis features of kaempferol against HT-29 cells might be related to i) cleavage of caspase-3, -7 , and -9 ; ii) increased mitochondrial membrane permeability; iii) increased cytochrome $\mathrm{C}$ release; iv) attenuation of 
Bcl-xL, phosphorylation, and reduction of Akt activity; v) augmentation of Bad; and vi) activation of the Fas ligand and caspase-8 [22]. Moreover, kaempferol suppressed DLD-1 colorectal cells by inhibiting cyclooxygenase (COX)-2 promoter activity [23].

Kaempferol can also be used as a chemopreventive agent against CRC. Nirmala and Ramanathan showed that kaempferol had a chemopreventive effect on tumors in Wistar male rats that were induced by 1,2-dimethylhydrazine [24].<smiles>O=c1c(O)c(-c2ccc(O)c(O)c2)oc2cc(O)cc(O)c12</smiles><smiles></smiles>

Quercetin

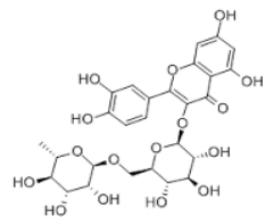

Rutin<smiles>O=C1C[C@H](c2ccc(O)c(O)c2)Oc2cc(O)cc(O)c21</smiles>

Eriodictyol<smiles>COc1ccc(-c2cc(=O)c3c(OC)c(OC)c(OC)c(OC)c3o2)cc1</smiles>

Tangeretin<smiles>Oc1cc(O)c2c(c1)OC(c1ccc(O)c(O)c1)C(O)C2</smiles>

Catechin family<smiles>Oc1cc(O)c2cc(O)c(-c3ccc(O)c(O)c3)[o+]c2c1</smiles>

Cyanidin
Kaempferol

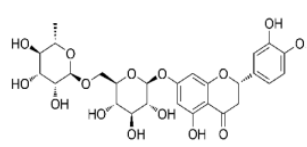

Hesperidin<smiles>COc1ccc(-c2cc(=O)c3c(O)cc(O)cc3o2)cc1</smiles>

Acacetin<smiles>O=c1cc(-c2ccc(O)c(O)c2)oc2cc(O)cc(O)c12</smiles>

Luteolin

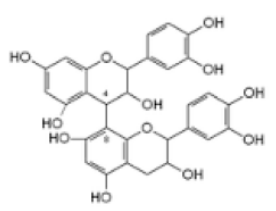

Proanthocyanidins<smiles></smiles>

Delphinidin

\section{Myricetin}

Myricetin is found in walnuts, grapes, and berries, as well as in fermented grapes such as red wine [25]. The anti-colon cancer property of myricetin has been investigated in HCT-15 and HCT-116 cell lines. The study authors claimed that myricetin increased the level of Bax and promoted release of apoptosis inducing factor (cytochrome C) from the mitochondria [26, 27].<smiles>O=c1c(O)c(-c2cc(O)c(O)c(O)c2)oc2cc(O)cc(O)c12</smiles><smiles>O=c1c(O)c(-c2ccc(O)c(O)c2)oc2cc(O)ccc12</smiles>

Fisetin<smiles>O=C1C[C@H](c2ccc(O)cc2)Oc2cc(O)cc(O)c21</smiles>

Naringenin<smiles>O=c1cc(-c2ccc(O)cc2)oc2cc(O)cc(O)c12</smiles>

Apigenin<smiles>O=c1cc(-c2ccccc2)oc2cc(O)c(O)c(O)c12</smiles>

Baicalein<smiles></smiles>

Pelargonidin<smiles></smiles>

Malvidin

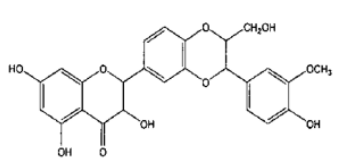

Silibinin<smiles>O=c1cc(-c2ccccc2)oc2cc(O)cc(O)c12</smiles>

Chrysin<smiles>COc1ccc(-c2cc(=O)c3c(OC)c(OC)c(OC)c(OC)c3o2)cc1OC</smiles>

Nobiletin<smiles></smiles>

Peonidin

Figure 1: Chemical formulas of main flavonoids. 


\section{Fisetin}

Fisetin is found in large amounts in strawberries and cucumbers [28]. Studies have demonstrated inhibition of the growth of colon cancer cell lines such as HT-29 and HCT-116 induced by fisetin. Growth inhibition of HT-29 cells via fisetin ensued through two main pathways, namely, the inhibition of cell growth and of DNA synthesis. Fisetin arrested HT-29 cells in the G2/M phase. Downstream experiments demonstrated reduced cyclin-dependent activity (CDK2 and CDK4) and consequently attenuation in cyclin E and D1 and in the strength of p21 expression [29]. Researchers have proposed that fisetin has the potential to reduce the expression level of the COX-2 gene, which could be the cause of growth inhibition [30]. Enhancement of expression of the COX-2 gene could occur through the activation of oncogenic pathways such as the Ras-MAPK pathway. After the expression of the COX-2 gene was increased, cell proliferation was promoted via stimulation of $\beta$-catenin/Tcf activity [31].

Although fisetin attenuates the COX-2 and MAPK pathways in HT-29 cells, the growth of HCT-116 cells was inhibited through the apoptosis mechanism. Several factors were involved in this mechanism, such as reduction of antiapoptotic Bcl-xL and Bcl-2 at the protein level and enhancement of proapoptotic Bad and Bim. Moreover, excitation of mitochondrial permeability and consequently activation of the caspase cascade, including caspase-3, $-7,-8$, and -9 , and downstream factors such as cytochrome $c$ are other means of promoting apoptosis. Activation of death receptors (Fas and tumor necrosis factor) by fisetin assisted in promoting apoptosis. In addition, fisetin increased p53 expression [32].

\section{Rutin}

Rutin is present in a wide range of fruits, including citrus, berries, peach, apple, and apricot, as well as in some vegetables such as parsley and tomatoes [33]. In vitro investigation of the rutin compound showed a slight trend towards inhibition of CRC cells such as HT-29 and CaCo-2 [13]. Rutin has been reported to have a role in causing DNA damage [34]. In vivo results on nude mice, which were made cancerous by injecting SW480, indicated that rutin has antiangiogenic activity against CRC [35]. Another study reported that rutin has the potential to reduce the number of aberrant crypt foci (ACF) in azoxymethane (AOM)-induced rats. Rutin also has the potential to induce apoptosis in rats by virtue of it being able to modify the expression level of Bax, Bcl-2, and caspase-9 [36]. The efficiency of rutin had also been explored in a study on F344 rats, which demonstrated inhibition in the outgrowth of ACF [37].

\section{Flavanones}

Flavanones are a group of flavonoids that are present in citrus fruits [38]. Hesperidin, naringenin, silibinin, and eriodictyol are members of this family.

\section{Hesperidin}

Hesperidin is a flavanone that is widely found in citrus fruits. It specifically upregulates caspase-3 transcription in SNU-C4 CRC cells [39]. This upregulation in mRNA initiates the apoptotic pathway. Hesperidin has also been reported to decrease the expression of Bcl-2 and to upregulate Bax expression [40].

\section{Naringenin}

Naringenin, which can be found in citrus fruits, has shown promising anti-CRC effects on HT-29 cells [41]. These effects were tested by assessing the ability of naringenin to activate a related signaling pathway of the apoptosis cascade in the presence of estrogen receptor $\beta$ (ER $\beta)$. One study showed that naringenin regulates ER $\beta$ activity and increases stimulation of p38/MAPK phosphorylation and caspase-3 activity [42]. In vivo studies indicated that naringenin could suppress the early stage of colon cancer by attenuating inducible nitric oxide synthase (iNOS) and COX-2 levels in carcinogen-injected rats [43, 44].

\section{Silibinin}

Silibinin is a flavonone that has been isolated from milk thistle [45]. The anticolorectal effect of this compound was extensively studied in various colon cancer cell lines such as HT-29, HCT-116, SW480, and LoVo. Silibinin has been shown to have the potential to inhibit HT-29 cells through different pathways [46]. In the presence of silibinin, cell cycle arrest occurred in G2/M. In mechanistic studies related to cell cycle progression, silibinin was associated with decreasing levels of CDK2, CDK4, cyclin E, and cyclin D1 and with the upregulation of p27 and p21 [47]. Although the antiproliferation and apoptotic effects of silibinin on HT-29 cells likely depend on attenuation of ERK and Akt, suppression of iNOS, COX, hypoxia-inducible factor-1 alpha (HIF-1 $\alpha$ ), and vascular endothelial growth factor (VEGF) also leads to an antiangiogenesis effect [48].

The inhibitory effect of silibinin on SW480 was reported to occur through four mechanisms: i) cell death and apoptosis via upregulation of caspase-3, -8 , and -9 [49]; ii) the Wnt- $\beta$-catenin pathway, whereby silibinin decreases $\beta$-catenin and Gsk- $\beta$ levels; iii) a 
decrease in angiogenesis regulators such as VEGF and iNOS; and iv) targeting of signaling molecules involved in proliferation and survival such as cyclin D and c-Myc [50]. Although silibinin has the potential to inhibit SW480 through apoptosis, growth inhibition of HCT-116 cells in the presence of this compound was independent of apoptosis and more related to suppression of p27, p21, cyclin B1, cyclin D1, and CDK2 [46]. Another study conducted in 2012 demonstrated that silibinin also had inhibitory effect on LoVo colon cancer cells and that this effect occurred through the suppression of matrix metalloproteinase (MMP)-2 and AP-1 binding activity [51].

In vivo studies of Wistar rats and $\mathrm{A} / \mathrm{J}$ mice induced by $\mathrm{AOM}$ also confirmed the anti-colorectal activity of silibinin. These extensive studies were performed to the level of gene expression and indicated that silibinin might be used as a chemopreventive compound in the battle against CRC in Wistar rats through two mechanisms: i) suppression of inflammatory receptors such as interleukin-1 (IL-1) and ii) induction of apoptosis via the downregulation of $\mathrm{Bcl}-2$ and the upregulation of Bax [52]. The chemopreventive mechanism of silibinin was also under investigation in A/J mice. Silibinin targeted $\beta$-catenin and IGF-1 in the Wnt and PI3K/Akt pathways, respectively [53].

\section{Eriodictyol}

Eriodictyol inhibited the proliferation of DLD-1 colorectal cell lines at a concentration of $22 \mu \mathrm{g} / \mathrm{ml}$. Eriodictyol is potent in preventing the growth of colon cancer by suppressing the transcription of the COX-2 gene [54]. No other data or research supports the use of this compound as an anti-colon cancer agent.

\section{Flavones}

The main sources of flavones are cereals and herbs [55]. The most important members of this family are acacetin, apigenin, chrysin, tangeretin, luteolin, baicalein, and nobiletin. In recent years, scientific and public interest in flavones has grown.

\section{Acacetin}

The main source of acacetin is Robinia pseudoacacia. SW480 cells that were exposed to acacetin showed reduced cell viability and cell arrest in G2/M. Investigators claimed that the functional group on the 4 ' position of acacetin and its analogs confers an effect on cell arrest [56]; the exact mechanism by which acacetin acts against colon cancer is, however, still unclear.

\section{Apigenin}

Apigenin is found in vegetables such as chamomile, celery, and parsley [57]. It has shown an inhibitory effect on some colon cancer cell lines such as SW480, HCT-116, CaCo-2, and HT-29. Further investigations showed that colon cancer cells were arrested in G2/M [56, 58]. The inhibitory effect of apigenin against HCT-116 cells occurred through the downregulation of cyclin B1, Cdc-2, and Cdc-25 and the upregulation of p53 and p21 [59]. Apigenin also induced ERK and p38 in the MAPK cascade [60] and decreased the expression of mammalian target of rapamycin (mTOR) and cyclin D1 in the p53 mutant HT-29 human colon adenocarcinoma cell line [61]. Moreover, apigenin inhibits SW480 cells by increasing the expression of caspase-3 and Bax and downregulating Bcl-2 [62].

In summary, it appears that in vivo findings were in accordance with in vitro outcomes. Turner et al. reported that apigenin has the potential to inhibit CRC induced by AOM in Sprague-Dawley (SD) rats via apoptosis [63].

\section{Chrysin}

Chrysin has been found in Passiflora caerulea, Pleurotus ostreatus, and Oroxylum indicum [64]. Exposure of SW480 CRC cells to chrysin inhibited cell growth, and colorectal cells were arrested in G2/M in the presence of chrysin [56]. The inhibitory effect of chrysin on cancer cells might cause inhibition of COX-2 expression via inhibition of nuclear factor IL-6 (NF-IL-6) [65]. Chrysin not only induces DNA fragmentation, but it may also promote apoptosis in CaCo-2 cells [66]. In vivo studies reported the chemopreventive effect of chrysin in male rats with colonic cancer induced by AOM [67]. Another in vivo study on preneoplastic colorectal lesions induced by 1, 2-dimethylhyrazine in female Wistar rats confirmed the efficiency of chrysin against CRC [68].

\section{Tangeretin}

The main source of tangeretin is citrus peel [69] and thus tangeretin is categorized as a citrus flavonoid. A paper published in 2007 reported that tangeretin suppressed proliferation by cell cycle arrest in G1 without apoptosis in the human colon cancer cell line HT-29 [70]. Multidrug-resistant (LoVo/Dx) human colon adenocarcinoma cells that were exposed to tangeretin were inhibited; the investigators concluded that the activity of tangeretin probably enhanced apoptosis activity through the induction of caspase- 3 in this cell line [71]. Tangeretin suppresses the proliferation of COLO-205 by blocking cell cycle progression in G1; reducing the expression of cyclin 
A, D, and E; reducing the effect of CDK2 and CDK4; and stimulating the activity of p21, p27, and p53 [72].

\section{Luteolin}

Luteolin is mainly found in vegetables rather than fruits [73], including celery, carrots, parsley, and mint. The anti-colon cancer effect of luteolin has been investigated in vitro in several colon cancer cell lines such as HCT-15, HT-29, CaCo-2, COLO-320 DM, and SW480. The studies together indicated that luteolin has the potential to control CRC through three main pathways: i) the apoptosis pathway by activating caspase-3, -7, and -9 in HT-29 cells [74]; ii) the PI3K/Akt and ERK pathways by inhibiting the IGF receptor (IGF-R) in HT-29 cells [75]; and iii) the Wnt/ $\beta$-catenin/GSK-3 $\beta$ signaling pathway by modulating GSK-3 $\beta$ in HCT-15 cells and inhibiting $\beta$-catenin in COLO-320 DM cells [76, 77]. Through these main pathways, luteolin was able to activate DNA damage in CaCo-2 cells [78]. Furthermore, cell cycle arrest of HT-29 cells was induced by modulation and inhibition of CDK2 and cyclin D [75, 76]. Luteolin also inhibited SW480 and CaCo- 2 cells by inducing cell cycle arrest in G2/M [79].

The outcome data of luteolin against CRC was evaluated in an in vivo study by using BALB/c mice induced by AOM. Findings from this animal experiment demonstrated that luteolin inhibited metastatic colon cancer by reduction of MMP-2 and MMP-9 [80]. Luteolin also inhibited iNOS and COX-2 [81, 82]. In addition, it activated lysosomal enzymes, inhibited caspase-3, and modulated Bcl-2 and Bax in the apoptosis pathway [83]. Inhibition of tumor growth occurred through the Wnt/ $\beta$-catenin pathway in the presence of luteolin. Moreover, the incidences of mucin-depleted foci and ACF were decreased by luteolin in BALB/c mice [84].

\section{Baicalein}

The inhibitory effect of baicalein, which is present in Indian trumpet flower and Chinese skullcap, or Scutellaria baicalensis, on human colon cancer was studied in vitro and in vivo [85]. Research indicated that baicalein had a significant inhibitory effect on HCT-116 cells. The mechanisms of effect of baicalein occur through three pathways: i) the extrinsic pathway of apoptosis, ii) by decreasing the incidence of inflammation, and iii) by impairment of tumor formation through inactivation of the PI3K/Akt pathway. Baicalein increased the expression of caspase- 3 and -8 , which are involved in apoptosis. The expression of NF-kB was inhibited, resulting in inhibition of iNOS, MMP-9, and MMP-2 genes, all of which are involved in inflammation [86, 87]. The effect of baicalein on HT-29 cells was also investigated. The data indicated that baicalein had the ability to increase cell arrest in the G1 phase. Baicalein attenuated the expression of $\mathrm{Bcl}-2$, whereas the expression of Bax was augmented. Moreover, induction of apoptosis was achieved by inactivation of the PI3K/Akt pathway [88]. Further studies on cancerous Institute for Cancer Research (ICR) mice induced by AOM supported the preventive effect of baicalein [86].

\section{Nobiletin}

The anti-CRC ability of nobiletin has been detected in both in vitro and in vivo studies. Nobiletin was able to suppress the proliferation of HT-29 cells through cell cycle arrest in G1 without inducing apoptosis [70]. One study indicated that this citrus flavonoid prevented cancer metastasis through reduced expression of MMP-7 [89]. The anti-cancer efficiency of nobiletin was tested at the in vivo level in several models, such as F344 rats, SD rats, $\mathrm{C} 57 \mathrm{BL} / \mathrm{KsJ}-\mathrm{db} / \mathrm{db}$ mice, and ICR mice. Nobiletin was introduced into cancer models and showed a chemopreventive effect as a result of reduced expression of prostaglandin E2 [89-92].

\section{Flavan-3-ols (flavanols)}

Flavan-3-ols are a class of flavonoids found in human foods and beverages [93]. There has been great interest in flavanols in nutrition and medicine because they have antioxidant properties. The best known member of the flavan-3-ol family is the catechin group, which is abundantly present in tea $[94,95]$.

\section{Catechins}

Besides being the main component of tea, catechins can also be found in grapes, apple, peas, wine, and cocoa. Catechins contain a benzopyran skeleton with an additional phenyl group at the second position. The catechin family includes the following: (+)-gallocatechin (GC), (-)-epicatechin (EC), (-)-epigallocatechin (EGC), (-)-epigallocatechin gallate (EGCG), and (-)-epicatechin 3-gallate (ECG) [96].

The antiproliferative properties of these compounds were investigated in CaCo-2, HT-29 (p53 mutant type), HCT-116 (p53 wild type), and SW480 (p53 mutant type) cell lines [97-100]. When these compounds were compared, EGCG had the most potent anti-colorectal inhibitory potential. Although EGCG had a significant inhibitory effect on HCT-116 and SW-480 cells, even stronger inhibition was observed against HCT-116 cells. Therefore, p53 might play an important antiproliferative role against colon cancer. Cell arrest occurred in the G1 and G2/M phases. Apoptosis was one of the main effects in the 
inhibition of HCT-116 cells. Moreover, when the different members of this family were compared, GC, EGC, and EGCG were shown to have better efficiency than EC and ECG, indicating that esterification of gallic acid with catechin could enhance the anti-cancer property of the compound [101].

Overall, the literature indicates that EGCG can cause apoptosis, cell cycle arrest, and DNA damage [102]. EGCG inhibited the binding of epidermal growth factor (EGF) to EGF receptor (EGFR) in the receptor tyrosine kinase pathway, induced the expression of caspase-3 and -9 , and caused mitochondrial damage in HT-29 cell lines [98]. EGCG instigated mitochondrial damage and apoptosis by interference with JNK [103]. EGCG has been shown to cause reduced MMP-7, MMP-9, and IGF-1R levels in HT-29 and CaCo-2 cell lines [104]. The inhibitory effect of EGCG on EGFR in SW480 cell lines occurs through the internalization of EGFR from the endosome. EGFR is therefore not able to return to the cell surface [105]. EGCG can block HCT-116 cells through two main mechanisms $i$ ) induction of reactive oxygen species (ROS), thereby activating p53, p21, and PUMA, which then leads to DNA damage; and ii) stimulation of caspase-3, caspase -9, and cytochrome $C$ release, which leads to cell apoptosis [106, 107].

The antiproliferative activity of EGCG was tested in vivo in an animal model. Colitis was induced in mice by injection of dextran sulfate sodium. Results indicated that the formation of ACF was decreased in the presence of EGCG. Further investigations into the molecular mechanism of EGCG revealed that it controlled the formation of ACF by attenuating the expression of PI3K/Akt/nuclear factor kappa B (NFkB) and the activation of the ERK pathway [108].

\section{Proanthocyanidin}

Proanthocyanidin is present in tea, cranberries, and grape seeds and has been shown to interrupt the proliferation of colorectal cells such as CaCo-2, HT-29, SW620, SW480, and HCT-116 [109, 110]. It suppresses HT-29 cells by i) disrupting the actin cytoskeleton, ii) inducing apoptosis by increasing caspase-3, iii) damaging DNA by increasing ROS levels, iv) arresting the cell cycle in G2, and $v$ ) inhibiting COX-2 expression [111-114]. The inhibitory effect of proanthocyanidin on HCT-116 cells was reported to be related to DNA damage, inhibition of the COX-2 gene, and promotion of apoptosis [109, 115]. The expression of PI3K was attenuated in the CaCo-2 cell line in the presence of proanthocyanidin [116]. Proanthocyanidin might also increase apoptosis in CaCo-2 cells [116]. The inhibition of SW620 cells (metastatic colon carcinoma) by proanthocyanidin can occur through several mechanisms such as increased activation of caspase-3, c-jun, NFkB, and p53 [117, 118].

In vitro results of proanthocyanidin activity has been confirmed in an in vivo study. AOM was used to induce colon cancer in F344 rats. ACF were shown to decrease in the presence of proanthocyanidin because of the activation of caspase-3 [119].

\section{Flavanonols}

Flavanonols are a class of flavonoids that possess a 3-hydroxy-2,3-dihydro-2-phenylchromen-4-one backbone. Flavanonols are present in red wine, as well as in many red, purple, and blue fruits and vegetables.

\section{Pelargonidin}

Pelargonidin is found in berries such as raspberries and strawberries. The efficiency of pelargonidin has been investigated against a variety of cell lines such as primary (CaCo-2) and metastatic (LoVo and LoVo/ADR) CRC cell lines and human colorectal adenocarcinoma (HT-29). No significant inhibitory effect has been reported in these cell lines [120, 121]. Mild inhibition of cell proliferation was reported, however, against HCT-116 cells at a concentration of $200 \mu \mathrm{g} / \mathrm{ml}$ [122].

\section{Peonidin}

Bilberry, blueberry, cherry, cranberry, and peach are the main sources of peonidin [114], which inhibits the growth of SW480 cells in a dose-dependent manner. Cell cycle arrest of SW480 cells occurred at the G1 phase in the presence of peonidin [123]. No other studies have been found in the literature describing anti-CRC effects of peonidin.

\section{Cyanidin}

Cyanidin is present in various fruits such as red apple, blackberry, blueberry, cherry, cranberry, peach, and plum [124]. Retrieved published articles did not show any significant results for cyanidin against primary (CaCo-2) or metastatic (LoVo and LoVo/ADR) colon cancer cell lines [125].

\section{Delphinidin}

Delphinidin is one of the main compounds in blueberries, and an anticancer effect of delphinidin on a human colon cancer cell line (colo205) has been reported [126]. The inhibitory effect of delphinidin on LoVo/ADR cell lines was also investigated. The data revealed that delphinidin inhibited metastatic CRC and that this may have been due to cellular ROS accumulation [125]. Further investigation of delphinidin indicated that it inhibited HT-29 human tumor cells through the suppression of EGFR [97]. A 
recent study on delphinidin claimed that it had antioxidant activity against human CRC HTC-116 and HT-29 cells and could also induce DNA damage [127]. In addition, delphinidin potently inhibited HTC-116 and HT-29 cell lines through the downregulation of HIF-1 and p27 by affecting the PI3K/Akt/mTOR signaling pathway [128]. HCT-116 cells treated with delphinidin suppressed the NF-kappa B pathway and activated the expression of caspase-3, -8 and -9 , resulting in cell cycle arrest in the $\mathrm{G} 2 / \mathrm{M}$ phase, thereby leading to apoptosis [129].

\section{Malvidin}

Blueberries are the main source of malvidin [130]. The antiproliferation effect of malvidin has been studied in colon cancer. Malvidin had no significant inhibitory effect on CaCo-2 and HCT-116 cells, nor did it demonstrate any effect on LoVo or LoVo/ADR cells $[125,131]$.

Table 1: Summary of the main flavonoids and their anti-colorectal cancer properties.

\begin{tabular}{|c|c|c|c|c|}
\hline Flavonoid & $\begin{array}{l}\text { Colon cancer cell } \\
\text { lines }\end{array}$ & Animal model & Signaling and target pathways & References \\
\hline Quercetin & $\begin{array}{l}\text { HT-29 } \\
\text { HCT-116 } \\
\text { SW480 }\end{array}$ & Rats & Reduces cyclin A; induces Cdc-2, p21, and Wnt- $\beta$-catenin & [9-16] \\
\hline Kaempferol & $\begin{array}{l}\text { HCT-116 } \\
\text { HT-29 } \\
\text { DLD-1 }\end{array}$ & $\begin{array}{l}\text { Wistar male } \\
\text { rats }\end{array}$ & $\begin{array}{l}\text { Induces DNA damage response; upregulates p53 and PUMA; activates mitochondria } \\
\text { permeability; induces cytochrome C release; reduces expression of CDK2, CDK4, cyclin D1, } \\
\text { cyclin E, and cyclin A; attenuates IGF-1; induces cleavage of caspase- } 3,-7,-8 \text {, and -9; attenuates } \\
\text { Bcl-xL, phosphorylation, and Akt activity; increases Bad; activates Fas inhibition of COX-2 } \\
\text { activity }\end{array}$ & {$[17-24]$} \\
\hline Myricetin & $\begin{array}{l}\text { НСТ-15 } \\
\text { НСТ-116 }\end{array}$ & --- & Induces Bax; induces release of apoptosis inducing factor & [25-27] \\
\hline Fisetin & $\begin{array}{l}\text { HCT-116 } \\
\text { HT-29 }\end{array}$ & --- & $\begin{array}{l}\text { Reduces CDK2 and CDK } 4 \text { and consequently attenuates cyclin E and D1 and strength of p21 } \\
\text { expression; reduces expression of COX-2 and MAPK-Ras; reduces Bcl-xL and Bcl-2; enhances } \\
\text { Bad and Bim, including caspase- } 3,-7,-8 \text {, and }-9 \text { and cytochrome c release; activates FasL and } \\
\text { TNF; increases p53 }\end{array}$ & [28-32] \\
\hline Rutin & $\begin{array}{l}\mathrm{HT}-29 \\
\mathrm{CaCo}-2\end{array}$ & $\begin{array}{l}\text { Nude mice, } \\
\text { F344 rats }\end{array}$ & Damages DNA; induces apoptosis; changes expression level of Bax, Bcl-2, and caspase-9 & {$[13,33-37]$} \\
\hline Hesperidin & SNU-C4 & --- & Increases caspase- 3 and Bax; decreases Bcl-2 & [39-40] \\
\hline Naringenin & HТ-29 & Rats & Regulates ER- $\beta$; induces MAPK/p38 and caspase-3; attenuates iNOS and COX-2 & [41-44] \\
\hline Silibinin & $\begin{array}{l}\text { HT-29 } \\
\text { HCT-116 } \\
\text { SW480 } \\
\text { LoVo }\end{array}$ & $\begin{array}{l}\text { Wistar rats, } \\
\mathrm{A} / \mathrm{J} \text { mice }\end{array}$ & $\begin{array}{l}\text { Decreases CDK2, CDK4, cyclin E, and cyclin D1; upregulates p27 and p21; attenuates ERK and } \\
\text { Akt; suppresses iNOS, COX, HIF-1 } \alpha \text {, and VEGF; upregulates caspase- } 3,-8 \text {, and -9; decreases } \\
\beta \text {-catenin and Gsk- } \beta \text { levels; decreases c-Myc; suppresses MMP-2 and AP-1; suppresses IL-1; } \\
\text { downregulates Bcl-2 and upregulates Bax; targets } \beta \text {-catenin and IGF-1 }\end{array}$ & {$[45-53]$} \\
\hline Eriodictyol & DLD-1 & --- & Reduces COX-2 level & [54] \\
\hline Acacetin & SW480 & -- & Unknown mechanism & [56] \\
\hline Apigenin & $\begin{array}{l}\text { SW } 480 \\
\text { HCT-116 CaCo-2 } \\
\text { HT-29 }\end{array}$ & SD rats & $\begin{array}{l}\text { Downregulates cyclin B1, Cdc-2, and Cdc-25; upregulates p53 and p21; induces ERK and p38; } \\
\text { decreases mTOR and cyclin D1; increases expression of caspase-3 and Bax; attenuates Bcl-2 } \\
\text { expression }\end{array}$ & [56-63] \\
\hline Chrysin & $\begin{array}{l}\text { Caco-2 } \\
\text { SW480 }\end{array}$ & Wistar rats & Inhibits COX-2 and NF-IL-6; induces DNA fragmentation; induces apoptosis & {$[56,64-68]$} \\
\hline Tangeretin & $\begin{array}{l}\text { HT-29 LoVo/Dx } \\
\text { COLO-205 }\end{array}$ & -- & $\begin{array}{l}\text { Increases caspase- } 3 \text { level; reduces cyclin A, D, and E; attenuates CDK2 and CDK4 activity; } \\
\text { instigates activity of p21 and p27 }\end{array}$ & [69-72] \\
\hline Luteolin & $\begin{array}{l}\text { HCT-15 } \\
\text { HT-29 } \\
\text { Caco-2 } \\
\text { COLO-320DM } \\
\text { SW480 }\end{array}$ & BALB/c mice & $\begin{array}{l}\text { Induces caspase-3,-7, and -9; inhibits PI3K/ Akt, ERK, IGF, } \beta \text {-catenin, GSK-3 } \beta \text {, MMP-2 and -9, } \\
\text { iNOS, COX-2, Bcl-2, Bax, CDK2, and cyclin D; damages DNA }\end{array}$ & [73-84] \\
\hline Baicalein & $\begin{array}{l}\text { HCT-116 } \\
\text { HT-29 }\end{array}$ & ICR mice & $\begin{array}{l}\text { Increases caspase- } 3 \text { and }-8 \text {; inhibits PI3K/Akt, NFkB, iNOS, and MMP-2 and -9; attenuates } \\
\text { Bcl-2; induces Bax }\end{array}$ & [85-88] \\
\hline Nobiletin & HT-29 & $\begin{array}{l}\text { C57BL/KsJ-db } \\
/ \text { db mice, } \\
\text { ICR mice, } \\
\text { SD rats, F344 } \\
\text { rats }\end{array}$ & Reduces MMP-7 and PGE2 & {$[70,89-92]$} \\
\hline $\begin{array}{l}\text { Catechin } \\
\text { family }\end{array}$ & $\begin{array}{l}\text { CaCo-2 } \\
\text { HT-29 } \\
\text { HCT-116 SW } 480\end{array}$ & Mice & $\begin{array}{l}\text { Induces DNA damage and mitochondrial damage by interference of JNK; induces caspase-3 } \\
\text { and -9; releases cytochrome C; inhibits binding of EGF to EGFR in receptor tyrosine kinase } \\
\text { pathway; reduces MMP-7, MMP-9, and IGF-1R; induces ROS; activates p53, p21, and PUMA; } \\
\text { attenuates PI3K/Akt/ NFkB; activates ERK }\end{array}$ & {$[93-108]$} \\
\hline $\begin{array}{l}\text { Proanthocya } \\
\text { nidin }\end{array}$ & $\begin{array}{l}\text { CaCo-2 } \\
\text { HT-29 } \\
\text { SW620 } \\
\text { SW } 480 \\
\text { HCT-116 }\end{array}$ & F344 rats & Inhibits COX-2 and PI3K; induces caspase-3; activates c-jun; increases NFkB and p53 activity & [109-119] \\
\hline Pelargonidin & $\begin{array}{l}\text { Caco-2 } \\
\text { LoVo } \\
\text { LoVo/ADR }\end{array}$ & --- & No significant effect & [120-122] \\
\hline
\end{tabular}




\begin{tabular}{|c|c|c|c|c|}
\hline & $\begin{array}{l}\text { НТ-29 } \\
\text { НCТ-116 }\end{array}$ & & & \\
\hline Peonidin & SW480 & -- & No significant effect & {$[114,123]$} \\
\hline Cyanidin & $\begin{array}{l}\text { CaCo-2 } \\
\text { LoVo LoVo/ADR }\end{array}$ & -- & No significant effect & {$[124,125]$} \\
\hline Delphinidin & $\begin{array}{l}\text { Colo205 } \\
\text { LoVo/ADR } \\
\text { HT-29 } \\
\text { HCT-116 }\end{array}$ & --- & $\begin{array}{l}\text { Induces ROS accumulation; suppresses EGFR; damages DNA; downregulates HIF-1, p27, } \\
\text { PI3K/Akt/mTOR, and NFKB; induces caspase- } 3,-8 \text {, and -9 }\end{array}$ & {$[97,125-129]$} \\
\hline Malvidin & $\begin{array}{l}\text { Caco-2 } \\
\text { HCT-116 LoVo } \\
\text { LoVo/ADR }\end{array}$ & -- & No significant effect & [125-131] \\
\hline
\end{tabular}

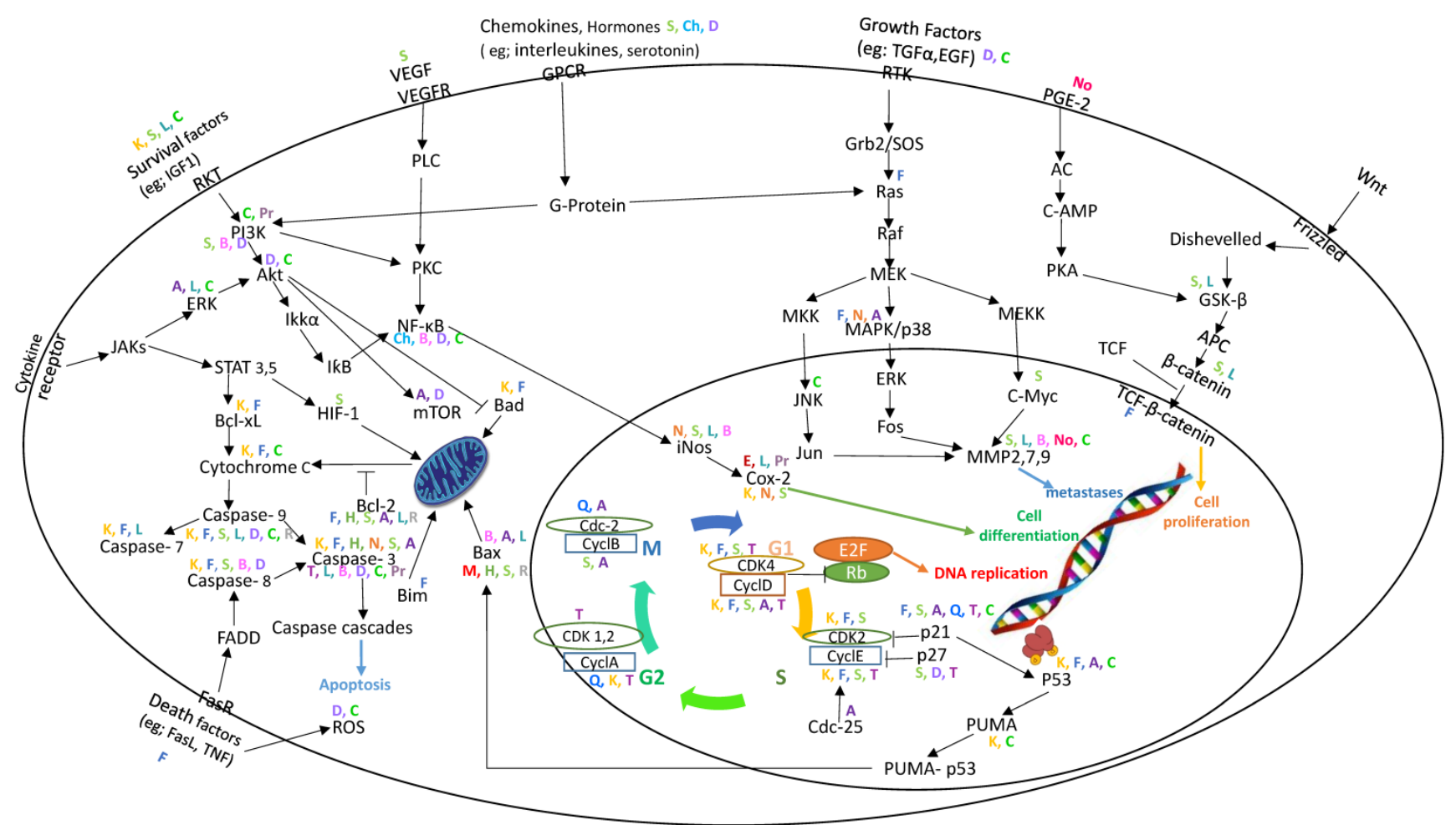

Kampferol: K, Myricetin: M, Fisetin: F, Hesperidin: H, Naringenin: N, Silibinin: S, Eriodictyol: E, Apigenin: A, Chrysin: Ch, Tangeritin: T, Luteolin: L, Nobiletin: No, Catechin: C, Delphinidin: D, Baicalein: B, Quercetin: Q, Proanthocyaniydin: pr Rutin:R

Figure 2: Association map of the role of the main flavonoids in their effect on signaling pathways in colorectal cancer. Different flavonoids are indicated by different colors.

\section{Conclusion}

Flavonoids belong to a large family of polyphenols and are well-known for their antioxidant properties. Furthermore, flavonoids have potential effects against several types of cancers such as breast, lung, and prostate. Although the mechanisms by which flavonoids act against colon cancer have been investigated, the exact details of these mechanisms are still unclear. In this review, we classified flavonoids on the basis of their chemical structures and the cell signaling pathways that each compound affects in CRC. We also summarized the in vitro and in vivo studies that have been performed for these compounds.

We prepared an association map from the information gathered in this review. Some points can be highlighted on the basis of this map (Figure 2). First, most of the compounds appear to activate the caspase cascades. Second, cyclin D, cyclin E, CDK2, and CDK4 are the major targets for most of the flavonoids that affect the cell cycle. Third, compounds that have effects on Jun and c-Myc prevent cancerous cells from undergoing metastasis. Fourth, Bax and $\mathrm{Bcl}-2$ are the main targets for flavonoids through the induction of apoptosis. Fifth, the majority of 
compounds have effects on iNOS, COX-2, and NFKB through the PI3K/Akt pathway.

From these findings, we can draw two conclusions. First, flavonoids are good candidates against colon cancer with strong efficacy. Part of this efficacy might be related to the ability of these compounds to block cancer cells through several pathways. Second, there may be an association between the chemical structure of flavonoids and specific signaling pathways. Although flavonoids share the same core ring, the targeted signaling pathway for each compound may be different. In addition, some of these flavonoids possess potent activity against colon cancer; there is a paucity of information, however, regarding the pathways. More clinical and preclinical studies are needed to elucidate the role of flavonoids against colon cancer.

\section{Acknowledgment}

The authors would like to thank the University of Malaya, Malaysia, for supporting this study through UMRG grant No. RG336-15AFR.

\section{Conflict of Interest}

The authors declare no conflict of interest.

\section{References}

1. Ferlay J, Soerjomataram I, Dikshit R, Eser S, Mathers C, Rebelo M, et al. Cancer incidence and mortality worldwide: sources, methods and major patterns in GLOBOCAN 2012. International Journal of Cancer. 2015; 136: E359-E86.

2. Sanjoaquin M, Appleby P, Thorogood M, Mann J, Key T. Nutrition, lifestyle and colorectal cancer incidence: a prospective investigation of 10998 vegetarians and non-vegetarians in the United Kingdom. British journal of cancer. 2004; 90: 118-21.

3. De Martel C, Ferlay J, Franceschi S, Vignat J, Bray F, Forman D, et al. Global burden of cancers attributable to infections in 2008: a review and synthetic analysis. The lancet oncology. 2012; 13: 607-15.

4. Ren W, Qiao Z, Wang H, Zhu L, Zhang L. Flavonoids: promising anticancer agents. Medicinal research reviews. 2003; 23: 519-34.

5. Taraphdar AK, Roy M, Bhattacharya R. Natural products as inducers of apoptosis: Implication for cancer therapy and prevention. Curr Sci. 2001; 80: 1387-96.

6. Kocic B, Kitic D, Brankovic S. Dietary flavonoid intake and colorectal cancer risk: evidence from human population studies. J BUON. 2013; 18: 34-43.

7. Cai $Y$, Luo Q, Sun M, Corke H. Antioxidant activity and phenolic compounds of 112 traditional Chinese medicinal plants associated with anticancer. Life sciences. 2004; 74: 2157-84.

8. Lu J, Papp LV, Fang J, Rodriguez-Nieto S, Zhivotovsky B, Holmgren A. Inhibition of mammalian thioredoxin reductase by some flavonoids: implications for myricetin and quercetin anticancer activity. Cancer research. 2006; 66: 4410-8.

9. Strom SS, Yamamura Y, Duphorne CM, Spitz MR, Babaian RJ, Pillow PC, et al. Phytoestrogen intake and prostate cancer: A case-control study using a new database. Nutr Cancer. 1999;33(1):20-5.

10. Kim WK, Bang MH, Kim ES, Kang NE, Jung KC, Cho HJ, et al. Quercetin decreases the expression of ErbB2 and ErbB3 proteins in HT-29 human colon cancer cells. The Journal of nutritional biochemistry. 2005; 16: 155-62.

11. van der Woude H, Gliszczyńska-Świgło A, Struijs K, Smeets A, Alink GM, Rietjens IM. Biphasic modulation of cell proliferation by quercetin at concentrations physiologically relevant in humans. Cancer letters. 2003; 200: 41-7.

12. Shan B-E, Wang M-X, Li R-q. Quercetin inhibit human SW480 colon cancer growth in association with inhibition of cyclin D1 and survivin expression through Wnt/ $\beta$-catenin signaling pathway. Cancer investigation. 2009; 27: 604-12.

13. Araújo JR, Gonçalves P, Martel F. Chemopreventive effect of dietary polyphenols in colorectal cancer cell lines. Nutrition Research. 2011; 31: 77-87.

14. Ramos S. Cancer chemoprevention and chemotherapy: dietary polyphenols and signalling pathways. Molecular nutrition \& food research. 2008; 52: 507-26.
15. Gee JM, Hara H, Johnson IT. Suppression of intestinal crypt cell proliferation and aberrant crypt foci by dietary quercetin in rats. Nutrition and cancer. 2002; 43: 193-201.

16. Park $\mathrm{CH}$, Chang JY, Hahm ER, Park S, Kim H-K, Yang CH. Quercetin, a potent inhibitor against $\beta$-catenin/Tcf signaling in SW480 colon cancer cells. Biochemical and biophysical research communications. 2005; 328: 227-34.

17. Häkkinen SH, Kärenlampi SO, Heinonen IM, Mykkänen HM, Törrönen AR Content of the flavonols quercetin, myricetin, and kaempferol in 25 edible berries. Journal of Agricultural and Food Chemistry. 1999; 47: 2274-9.

18. de Vrie JH, Janssen PK, Hollman PC, van Staveren WA, Katan MB. Consumption of quercetin and kaempferol in free-living subjects eating a variety of diets. Cancer letters. 1997; 114: 141-4.

19. Li W, Du B, Wang T, Wang S, Zhang J. Kaempferol induces apoptosis in human HCT116 colon cancer cells via the Ataxia-Telangiectasia Mutated-p53 pathway with the involvement of p53 Upregulated Modulator of Apoptosis. Chemico-Biological Interactions. 2009; 177: 121-7.

20. Cho H, Kwon G, Park J. Kaempferol induces cell cycle arrest and apoptosis in HT-29 human colon cancer cells. FASEB Journal 2005\%:A1694-A.

21. Lee HS, Cho HJ, Kwon GT, Park JHY. Kaempferol Downregulates Insulin-like Growth Factor-I Receptor and ErbB3 Signaling in HT-29 Human Colon Cancer Cells. Journal of cancer prevention. 2014; 19: 161.

22. Lee HS, Cho HJ, Yu R, Lee KW, Chun HS, Park JHY. Mechanisms underlying apoptosis-inducing effects of Kaempferol in HT-29 human colon cancer cells. International journal of molecular sciences. 2014; 15: 2722-37.

23. Mutoh M, Takahashi M, Fukuda K, Matsushima-Hibiya Y, Mutoh H, Sugimura $\mathrm{T}$, et al. Suppression of cyclooxygenase-2 promoter-dependent transcriptional activity in colon cancer cells by chemopreventive agents with a resorcin-type structure. Carcinogenesis. 2000; 21: 959-63.

24. Nirmala P, Ramanathan M. Effect of kaempferol on lipid peroxidation and antioxidant status in 1,2-dimethyl hydrazine induced colorectal carcinoma in rats. European journal of pharmacology. 2011; 654: 75-9.

25. Lee J-H, Johnson JV, Talcott ST. Identification of ellagic acid conjugates and other polyphenolics in muscadine grapes by HPLC-ESI-MS. Journal of agricultural and food chemistry. 2005; 53: 6003-10.

26. Kim ME, Ha TK, Yoon JH, Lee JS. Myricetin induces cell death of human colon cancer cells via BAX/BCL2-dependent pathway. Anticancer research. 2014; 34: 701-6.

27. Shiomi K, Kuriyama I, Yoshida H, Mizushina Y. Inhibitory effects of myricetin on mammalian DNA polymerase, topoisomerase and human cancer cell proliferation. Food chemistry. 2013; 139: 910-8.

28. Adhami VM, Syed DN, Khan N, Mukhtar H. Dietary flavonoid fisetin: a novel dual inhibitor of PI3K/Akt and mTOR for prostate cancer management. Biochemical pharmacology. 2012; 84: 1277-81.

29. Lu X, Cho HJ, Lee HS, Chun HS, Kwon DY, Park JH. Fisetin inhibits the activities of cyclin-dependent kinases leading to cell cycle arrest in HT-29 human colon cancer cells. The Journal of nutrition. 2005; 135: 2884-90.

30. Suh Y, Afaq F, Johnson JJ, Mukhtar H. A plant flavonoid fisetin induces apoptosis in colon cancer cells by inhibition of COX2 and Wnt/EGFR/NF-kB-signaling pathways. Carcinogenesis. 2009; 30: 300-7.

31. Greenhough A, Smartt HJ, Moore AE, Roberts HR, Williams AC, Paraskeva C, et al. The COX-2/PGE2 pathway: key roles in the hallmarks of cancer and adaptation to the tumour microenvironment. Carcinogenesis. 2009; 30: 377-86.

32. Lim DY, Park JHY. Induction of p53 contributes to apoptosis of HCT-116 human colon cancer cells induced by the dietary compound fisetin. American Journal of Physiology-Gastrointestinal and Liver Physiology. 2009; 296: G1060-G8.

33. Tomas-Lorente F, Garcia-Viguera C, Ferreres F, Tomas-Barberan FA. Phenolic compounds analysis in the determination of fruit jam genuineness. Journal of Agricultural and Food Chemistry. 1992; 40: 1800-4.

34. Ramos AA, Marques F, Fernandes-Ferreira M, Pereira-Wilson C. Water extracts of tree Hypericum sps. protect DNA from oxidative and alkylating damage and enhance DNA repair in colon cells. Food and Chemical Toxicology. 2013; 51: 80-6.

35. Alonso-Castro AJ, Domínguez F, García-Carrancá A. Rutin exerts antitumor effects on nude mice bearing SW480 tumor. Archives of medical research. 2013; 44: 346-51.

36. Volate SR, Davenport DM, Muga SJ, Wargovich MJ. Modulation of aberrant crypt foci and apoptosis by dietary herbal supplements (quercetin, curcumin, silymarin, ginseng and rutin). Carcinogenesis. 2005; 26: 1450-6.

37. Wargovich MJ, Jimenez A, McKee K, Steele VE, Velasco M, Woods J, et al. Efficacy of potential chemopreventive agents on rat colon aberrant crypt formation and progression. Carcinogenesis. 2000; 21: 1149-55.

38. Di Majo D, Giammanco M, La Guardia M, Tripoli E, Giammanco S, Finotti E. Flavanones in Citrus fruit: Structure-antioxidant activity relationships. Food Research International. 2005; 38: 1161-6.

39. Tanaka T, Makita H, Kawabata K, Mori H, Kakumoto M, Satoh K, et al Chemoprevention of azoxymethane-induced rat colon carcinogenesis by the naturally occurring flavonoids, diosmin and hesperidin. Carcinogenesis. 1997; 18: 957-65.

40. Park H, Kim M-J, Ha E, Chung J-H. Apoptotic effect of hesperidin through caspase 3 activation in human colon cancer cells, SNU-C4. Phytomedicine. 2008; 15: 147-51

41. Frydoonfar $\mathrm{H}, \mathrm{McG}$ rath $\mathrm{D}$, Spigelman A. The variable effect on proliferation of a colon cancer cell line by the citrus fruit flavonoid Naringenin. Colorectal Disease. 2003; 5: 149-52. 
42. Totta P, Acconcia F, Leone S, Cardillo I, Marino M. Mechanisms of Naringenin-induced Apoptotic Cascade in Cancer Cells: Involvement of Estrogen Receptor a and B Signalling. IUBMB life. 2004; 56: 491-9.

43. Vanamala J, Leonardi T, Patil BS, Taddeo SS, Murphy ME, Pike LM, et al. Suppression of colon carcinogenesis by bioactive compounds in grapefruit. Carcinogenesis. 2006; 27: 1257-65.

44. Leonardi T, Vanamala J, Taddeo SS, Davidson LA, Murphy ME, Patil BS, et al. Apigenin and naringenin suppress colon carcinogenesis through the aberrant crypt stage in azoxymethane-treated rats. Experimental biology and medicine. 2010; $235: 710-7$

45. Bhatia N, Zhao J, Wolf DM, Agarwal R. Inhibition of human carcinoma cell growth and DNA synthesis by silibinin, an active constituent of milk thistle: comparison with silymarin. Cancer letters. 1999; 147: 77-84.

46. Hogan FS, Krishnegowda NK, Mikhailova M, Kahlenberg MS. Flavonoid, silibinin, inhibits proliferation and promotes cell-cycle arrest of human colon cancer. Journal of Surgical Research. 2007; 143: 58-65.

47. Agarwal C, Singh RP, Dhanalakshmi S, Tyagi AK, Tecklenburg M, Sclafani RA, et al. Silibinin upregulates the expression of cyclin-dependent kinase inhibitors and causes cell cycle arrest and apoptosis in human colon carcinoma HT-29 cells. Oncogene. 2003; 22: 8271-82.

48. Singh RP, Gu M, Agarwal R. Silibinin inhibits colorectal cancer growth by inhibiting tumor cell proliferation and angiogenesis. Cancer Research. 2008; 68: 2043-50.

49. Kauntz H, Bousserouel S, Gossé F, Raul F. Silibinin triggers apoptotic signaling pathways and autophagic survival response in human colon adenocarcinoma cells and their derived metastatic cells. Apoptosis. 2011; 16: 1042-53.

50. Velmurugan B, Gangar SC, Kaur M, Tyagi A, Deep G, Agarwal R. Silibinin exerts sustained growth suppressive effect against human colon carcinoma SW480 xenograft by targeting multiple signaling molecules. Pharmaceutical research. 2010; 27: 2085-97.

51. Lin C-M, Chen Y-H, Ma H-P, Wang B-W, Chiu J-H, Chua S-K, et al. Silibinin inhibits the invasion of IL-6-stimulated colon cancer cells via selective JNK/AP-1/MMP-2 modulation in vitro. Journal of agricultural and food chemistry. 2012; 60: 12451-7.

52. Kauntz H, Bousserouel S, Gosse F, Marescaux J, Raul F. Silibinin, a natural flavonoid, modulates the early expression of chemoprevention biomarkers in a preclinical model of colon carcinogenesis. International journal of oncology. 2012; 41: 849-54.

53. Ravichandran K, Velmurugan B, Gu M, Singh RP, Agarwal R. Inhibitory effect of silibinin against azoxymethane-induced colon tumorigenesis in A/J mice. Clinical Cancer Research. 2010; 16: 4595-606.

54. Mutoh M, Takahashi M, Fukuda K, Komatsu H, Enya T, Matsushima-Hibiya $Y$, et al. Suppression by Flavonoids of Cyclooxygenase-2 Promoter-dependent Transcriptional Activity in Colon Cancer Cells: Structure-Activity Relationship. Cancer Science. 2000; 91: 686-91.

55. Chun OK, Chung SJ, Song WO. Estimated dietary flavonoid intake and major food sources of US adults. The Journal of nutrition. 2007; 137: 1244-52.

56. Wang W, VanAlstyne PC, Irons KA, Chen S, Stewart JW, Birt DF. Individual and interactive effects of apigenin analogs on G2/M cell-cycle arrest in human colon carcinoma cell lines. Nutrition and cancer. 2004; 48: 106-14.

57. Hostetler GL, Riedl KM, Schwartz SJ. Effects of food formulation and thermal processing on flavones in celery and chamomile. Food chemistry. 2013; 141: 1406-11.

58. Wang W, Heideman L, Chung CS, Pelling JC, Koehler KJ, Birt DF. Cell-cycle arrest at $\mathrm{G} 2 / \mathrm{M}$ and growth inhibition by apigenin in human colon carcinoma cell lines. Molecular carcinogenesis. 2000; 28: 102-10.

59. Lee Y, Sung B, Kang YJ, Kim DH, Jang J-Y, Hwang SY, et al. Apigenin-induced apoptosis is enhanced by inhibition of autophagy formation in HCT116 human colon cancer cells. International journal of oncology. 2014; 44: 1599-606.

60. Van Dross R, Xue Y, Knudson A, Pelling JC. The chemopreventive bioflavonoid apigenin modulates signal transduction pathways in keratinocyte and colon carcinoma cell lines. The Journal of nutrition. 2003; 133: 3800S-4S.

61. Turktekin M, Konac E, Onen HI, Alp E, Yilmaz A, Menevse S. Evaluation of the effects of the flavonoid apigenin on apoptotic pathway gene expression on the colon cancer cell line (HT29). Journal of medicinal food. 2011; 14: 1107-17.

62. Murthy KC, Kim J, Vikram A, Patil BS. Differential inhibition of human colon cancer cells by structurally similar flavonoids of citrus. Food Chemistry. 2012; 132: $27-34$

63. Turner ND, Vanamala J, Leonardi T, Patil BS, Murphy ME, Liu YC, et al. Comparison of the chemoprotection conferred by grapefruit and isolated bioactive compounds against colon cancer. 2006

64. Adewale O, Brimson J, Odunola O, Gbadegesin M, Owumi S, Isidoro C, et al. The Potential for Plant Derivatives against Acrylamide Neurotoxicity. Phytotherapy Research. 2015

65. Woo KJ, Jeong Y-J, Inoue H, Park J-W, Kwon TK. Chrysin suppresses lipopolysaccharide-induced cyclooxygenase-2 expression through the inhibition of nuclear factor for IL-6 (NF-IL6) DNA-binding activity. FEBS letters. 2005; 579: 705-11.

66. Schumacher M, Hautzinger A, Rossmann A, Holzhauser S, Popovic D, Hertrampf A, et al. Chrysin blocks topotecan-induced apoptosis in Caco-2 cells in spite of inhibition of ABC-transporters. Biochemical pharmacology. 2010; 80: 471-9.
67. Miyamoto $\mathrm{S}$, Kohno $\mathrm{H}$, Suzuki R, Sugie $\mathrm{S}$, Murakami A, Ohigashi $\mathrm{H}$, et al. Preventive effects of chrysin on the development of azoxymethane-induced colonic aberrant crypt foci in rats. Oncology reports. 2006; 15: 1169-73.

68. Sequetto PL, Oliveira TT, Soares ÍA, Maldonado IR, Mello VJ, Pizziolo VR, et al. The flavonoid chrysin attenuates colorectal pathological remodeling reducing the number and severity of pre-neoplastic lesions in rats exposed to the carcinogen 1, 2-dimethylhydrazine. Cell and tissue research. 2013; 352: 327-39.

69. Jeong S-M, Kim S-Y, Kim D-R, Jo S-C, Nam K, Ahn D, et al. Effect of heat treatment on the antioxidant activity of extracts from citrus peels. Journal of agricultural and food chemistry. 2004; 52: 3389-93.

70. Morley KL, Ferguson PJ, Koropatnick J. Tangeretin and nobiletin induce G1 cell cycle arrest but not apoptosis in human breast and colon cancer cells. Cancer letters. 2007; 251: 168-78.

71. Wesołowska O, Wiśniewski J, Środa-Pomianek K, Bielawska-Pohl A, Paprocka M, Duś D, et al. Multidrug resistance reversal and apoptosis induction in human colon cancer cells by some flavonoids present in citrus plants. Journal of natural products. 2012; 75: 1896-902.

72. Pan M-H, Chen W-J, Lin-Shiau S-Y, Ho C-T, Lin J-K. Tangeretin induces cell-cycle G1 arrest through inhibiting cyclin-dependent kinases 2 and 4 activities as well as elevating Cdk inhibitors p21 and p27 in human colorectal carcinoma cells. Carcinogenesis. 2002; 23: 1677-84.

73. Hertog MG, Hollman PC, Katan MB. Content of potentially anticarcinogenic flavonoids of 28 vegetables and 9 fruits commonly consumed in the Netherlands. Journal of agricultural and food chemistry. 1992; 40: 2379-83.

74. Attoub S, Hassan AH, Vanhoecke B, Iratni R, Takahashi T, Gaben A-M, et al. Inhibition of cell survival, invasion, tumor growth and histone deacetylase activity by the dietary flavonoid luteolin in human epithelioid cancer cells. European journal of pharmacology. 2011; 651: 18-25.

75. Lim DY, Cho HJ, Kim J, Nho CW, Lee KW, Park JH. Luteolin decreases IGF-II production and downregulates insulin-like growth factor-I receptor signaling in HT-29 human colon cancer cells. BMC gastroenterology. 2012; 12: 9.

76. Pandurangan AK. Potential targets for prevention of colorectal cancer: a focus on PI3K/Akt/mTOR and Wnt pathways. Asian Pac J Cancer Prev. 2013; 14: 2201-5.

77. Baskar AA, Ignacimuthu S, Michael GP, Al Numair KS. Cancer chemopreventive potential of luteolin-7-O-glucoside isolated from Ophiorrhiza mungos Linn. Nutrition and cancer. 2011; 63: 130-8.

78. Ramos AA, Pereira-Wilson C, Collins AR. Protective effects of ursolic acid and luteolin against oxidative DNA damage include enhancement of DNA repair in Caco-2 cells. Mutation Research/Fundamental and Molecular Mechanisms of Mutagenesis. 2010; 692: 6-11.

79. Wang L, Xie K, Huo H, Shang F, Zou W, Xie M. Luteolin Inhibits Proliferation Induced by IGF-1 Pathway Dependent ERa in Human Breast Cancer MCFS7 Cells. Asian Pacific Journal of Cancer Prevention. 2012: 13: 1431-7.

80. Pandurangan A, Dharmalingam P, Sadagopan S, Ganapasam S. Luteolin inhibits matrix metalloproteinase 9 and 2 in azoxymethane-induced colon carcinogenesis. Human \& experimental toxicology. 2014; 33: 1176-85.

81. Pandurangan A, Ananda Sadagopan S, Dharmalingam P. Inhibitory effect of luteolin on azoxymethane-induced colon carcinogenesis: involvement of iNOS and COX-2. Pharmacog Magazine. 2013.

82. Pandurangan AK, Kumar SAS, Dharmalingam P, Ganapasam S. Luteolin, a bioflavonoid inhibits azoxymethane-induced colon carcinogenesis: Involvement of iNOS and COX-2. Pharmacognosy magazine. 2014; 10: S306.

83. Pandurangan AK, Ananda Sadagopan SK, Dharmalingam P, Ganapasam S. Luteolin, a bioflavonoid inhibits Azoxymethane-induced colorectal cancer through activation of Nrf2 signaling. Toxicology mechanisms and methods. 2013; $24: 13-20$.

84. Ashokkumar P, Sudhandiran G. Protective role of luteolin on the status of lipid peroxidation and antioxidant defense against azoxymethane-induced experimental colon carcinogenesis. Biomedicine \& Pharmacotherapy. 2008; 62: 590-7.

85. Donald G, Hertzer K, Eibl G. Baicalein-an intriguing therapeutic phytochemical in pancreatic cancer. Current drug targets. 2012; 13: 1772.

86. Kim DH, Hossain MA, Kang YJ, Jang JY, Lee YJ, Im E, et al. Baicalein, an active component of Scutellaria baicalensis Georgi, induces apoptosis in human colon cancer cells and prevents AOM/DSS-induced colon cancer in mice. International journal of oncology. 2013; 43: 1652-8.

87. Kim SD, Lee YJ, Baik JS, Han JY, Lee CG, Heo K, et al. Baicalein inhibits agonist-and tumor cell-induced platelet aggregation while suppressing pulmonary tumor metastasis via cAMP-mediated VASP phosphorylation along with impaired MAPKs and PI3K-Akt activation. Biochemical pharmacology. 2014; 92: 251-65.

88. Kim S-J, Kim H-J, Kim H-R, Lee S-H, Cho S-D, Choi C-S, et al. Antitumor actions of baicalein and wogonin in HT-29 human colorectal cancer cells. Molecular medicine reports. 2012; 6: 1443-9.

89. Kawabata K, Murakami A, Ohigashi H. Nobiletin, a citrus flavonoid, down-regulates matrix metalloproteinase-7 (matrilysin) expression in HT-29 human colorectal cancer cells. Bioscience, biotechnology, and biochemistry. 2005; 69: 307-14

90. Miyamoto S, Yasui Y, Ohigashi H, Tanaka T, Murakami A. Dietary flavonoids suppress azoxymethane-induced colonic preneoplastic lesions in male C57BL/KsJ-db/db mice. Chem Biol Interact. 2010; 183: 276-83. 
91. Miyamoto S, Yasui Y, Tanaka T, Ohigashi H, Murakami A. Suppressive effects of nobiletin on hyperleptinemia and colitis-related colon carcinogenesis in male ICR mice. Carcinogenesis. 2008; 29: 1057-63.

92. Suzuki R, Kohno H, Murakami A, Koshimizu K, Ohigashi H, Yano M, et al. Citrus nobiletin inhibits azoxymethane-induced large bowel carcinogenesis in rats. Biofactors. 2004; 21: 111-4.

93. Aron PM, Kennedy JA. Flavan-3-ols: Nature, occurrence and biological activity. Molecular nutrition \& food research. 2008; 52: 79-104.

94. Actis-Goretta L, Ottaviani JI, Keen CL, Fraga CG. Inhibition of angiotensin converting enzyme (ACE) activity by flavan-3-ols and procyanidins. FEBS letters. 2003; 555: 597-600.

95. Nanjo F, Goto K, Seto R, Suzuki M, Sakai M, Hara Y. Scavenging effects of tea catechins and their derivatives on 1,1-diphenyl-2-picrylhydrazyl radical. Free Radical Biology and Medicine. 1996; 21: 895-902.

96. Chen D, Wan SB, Yang H, Yuan J, Chan TH, Dou QP. EGCG, green tea polyphenols and their synthetic analogs and prodrugs for human cancer prevention and treatment. Advances in clinical chemistry. 2011; 53: 155.

97. Fridrich D, Teller N, Esselen M, Pahlke G, Marko D. Comparison of delphinidin, quercetin and (-)-epigallocatechin-3-gallate as inhibitors of the EGFR and the ErbB2 receptor phosphorylation. Molecular nutrition \& food research. 2008; 52: 815-22.

98. Adachi S, Nagao T, Ingolfsson HI, Maxfield FR, Andersen OS, Kopelovich L, et al. The inhibitory effect of (-)-epigallocatechin gallate on activation of the epidermal growth factor receptor is associated with altered lipid order in HT29 colon cancer cells. Cancer Research. 2007; 67: 6493-501.

99. Shimizu M, Shirakami Y, Sakai H, Tatebe H, Nakagawa T, Hara Y, et al. EGCG inhibits activation of the insulin-like growth factor (IGF)/IGF-1 receptor axis in human hepatocellular carcinoma cells. Cancer letters. 2008; 262: 10-8.

100. Shimizu M, Deguchi A, Lim JT, Moriwaki H, Kopelovich L, Weinstein IB. (-)-Epigallocatechin gallate and polyphenon $\mathrm{E}$ inhibit growth and activation of the epidermal growth factor receptor and human epidermal growth factor receptor-2 signaling pathways in human colon cancer cells. Clinical Cancer Research. 2005; 11: 2735-46.

101. Du G-I, Zhang Z, Wen X-D, Yu C, Calway T, Yuan C-S, et al. Epigallocatechin Gallate (EGCG) is the most effective cancer chemopreventive polyphenol in green tea. Nutrients. 2012; 4: 1679-91.

102. Berger SJ, Gupta S, Belfi CA, Gosky DM, Mukhtar H. Green tea constituent (-)-epigallocatechin-3-gallate inhibits topoisomerase I activity in human colon carcinoma cells. Biochemical and biophysical research communications. 2001; 288: 101-5.

103. Chen C, Shen G, Hebbar V, Hu R, Owuor ED, Kong A-NT. Epigallocatechin-3-gallate-induced stress signals in HT-29 human colon adenocarcinoma cells. Carcinogenesis. 2003; 24: 1369-78.

104. Shimizu M, Deguchi A, Hara Y, Moriwaki H, Weinstein IB. EGCG inhibits activation of the insulin-like growth factor-1 receptor in human colon cancer cells. Biochemical and biophysical research communications. 2005; 334: 947-53.

105. Adachi S, Nagao T, To S, Joe AK, Shimizu M, Matsushima-Nishiwaki R, et al. (-)-Epigallocatechin gallate causes internalization of the epidermal growth factor receptor in human colon cancer cells. Carcinogenesis. 2008; 29: 1986-93.

106. Ahmed K, Wei Z-L, Zhao Q-L, Nakajima N, Matsunaga T, Ogasawara M, et al. Role of fatty acid chain length on the induction of apoptosis by newly synthesized catechin derivatives. Chemico-biological interactions. 2010; 185: 182-8

107. Thakur VS, Amin AR, Paul RK, Gupta K, Hastak K, Agarwal MK, et al. p53-Dependent p21-mediated growth arrest pre-empts and protects HCT116 cells from PUMA-mediated apoptosis induced by EGCG. Cancer letters. 2010; 296: 225-32

108. Chiou Y-S, Ma NJ-L, Sang S, Ho C-T, Wang Y-J, Pan M-H. Peracetylated (-)-epigallocatechin-3-gallate (AcEGCG) potently suppresses dextran sulfate sodium-induced colitis and colon tumorigenesis in mice. Journal of agricultural and food chemistry. 2012; 60: 3441-51.

109. Seeram NP, Adams LS, Hardy ML, Heber D. Total cranberry extract versus its phytochemical constituents: antiproliferative and synergistic effects against human tumor cell lines. Journal of agricultural and food chemistry. 2004; 52: 2512-7.

110. Howell AB, Reed JD, Krueger CG, Winterbottom R, Cunningham DG, Leahy M. A-type cranberry proanthocyanidins and uropathogenic bacterial anti-adhesion activity. Phytochemistry. 2005; 66: 2281-91.

111. Chung W-G, Miranda CL, Stevens JF, Maier CS. Hop proanthocyanidins induce apoptosis, protein carbonylation, and cytoskeleton disorganization in human colorectal adenocarcinoma cells via reactive oxygen species. Food and chemical toxicology. 2009; 47: 827-36.

112. Gorlach S, Wagner W, Podsędek A, Szewczyk K, Koziołkiewicz M, Dastych J. Procyanidins from Japanese quince (Chaenomeles japonica) fruit induce apoptosis in human colon cancer Caco-2 cells in a degree of polymerization-dependent manner. Nutrition and cancer. 2011; 63: 1348-60.

113. Lizarraga D, Lozano C, Briedé J, Van Delft J, Touriño S, Centelles J, et al. The importance of polymerization and galloylation for the antiproliferative properties of procyanidin-rich natural extracts. FEBS journal. 2007; 274: 4802-11.

114. Seeram NP, Adams LS, Zhang Y, Lee R, Sand D, Scheuller HS, et al. Blackberry, black raspberry, blueberry, cranberry, red raspberry, and strawberry extracts inhibit growth and stimulate apoptosis of human cancer cells in vitro. Journal of agricultural and food chemistry. 2006; 54: 9329-39.
115. Lizárraga D, Touriño S, Reyes-Zurita FJ, de Kok TM, van Delft JH, Maas LM, et al. Witch Hazel (Hamamelis virginiana) Fractions and the Importance of Gallate Moieties $\square$ Electron Transfer Capacities in Their Antitumoral Properties. Journal of agricultural and food chemistry. 2008; 56: 11675-82

116. Engelbrecht A-M, Mattheyse M, Ellis B, Loos B, Thomas M, Smith R, et al. Proanthocyanidin from grape seeds inactivates the PI3-kinase/PKB pathway and induces apoptosis in a colon cancer cell line. Cancer letters. 2007; 258: 144-53.

117. Maldonado ME, Bousserouel S, Gossé F, Lobstein A, Raul F. Implication of NF-kB and p53 in the expression of TRAIL-death receptors and apoptosis by apple procyanidins in human metastatic SW620 cells. Biomedica. 2010; 30: 577-86.

118. Gossé F, Guyot S, Roussi S, Lobstein A, Fischer B, Seiler N, et al. Chemopreventive properties of apple procyanidins on human colon cancer-derived metastatic SW620 cells and in a rat model of colon carcinogenesis. Carcinogenesis. 2005; 26: 1291-5.

119. Nomoto H, ligo M, Hamada H, Kojima S, Tsuda H. Chemoprevention of colorectal cancer by grape seed proanthocyanidin is accompanied by a decrease in proliferation and increase in apoptosis. Nutrition and cancer. 2004; 49: 81-8.

120. Cvorovic J, Tramer F, Granzotto M, Candussio L, Decorti G, Passamonti S. Oxidative stress-based cytotoxicity of delphinidin and cyanidin in colon cancer cells. Arch Biochem Biophys. 2010; 501: 151-7.

121. Jing $\mathrm{P}$, Bomser JA, Schwartz SJ, He J, Magnuson BA, Giusti MM. Structure-function relationships of anthocyanins from various anthocyanin-rich extracts on the inhibition of colon cancer cell growth. J Agric Food Chem. 2008; 56: 9391-8.

122. Zhang Y, Vareed SK, Nair MG. Human tumor cell growth inhibition by nontoxic anthocyanidins, the pigments in fruits and vegetables. Life sciences. 2005; 76: 1465-72.

123. Lim $\mathrm{S}, \mathrm{Xu} J$ Kim J Chen TY, $\mathrm{Su} X$ Standard J et al. Role of anthocyanin-enriched purple-fleshed sweet potato p40 in colorectal cancer prevention. Molecular nutrition \& food research. 2013; 57: 1908-17.

124. Wu X, Prior RL. Systematic identification and characterization of anthocyanins by HPLC-ESI-MS/MS in common foods in the United States: fruits and berries. Journal of agricultural and food chemistry. 2005; 53: 2589-99.

125. Cvorovic J, Tramer F, Granzotto M, Candussio L, Decorti G, Passamonti S. Oxidative stress-based cytotoxicity of delphinidin and cyanidin in colon cancer cells. Archives of biochemistry and biophysics. 2010; 501: 151-7.

126. Zu X-y, Zhang Z-Y, Zhang X-W, Yoshioka M, Yang Y-N, Li J. Anthocyanins extracted from Chinese blueberry (Vaccinium uliginosum L.) and its anticancer effects on DLD-1 and COLO205 cells. Chinese medical journal. 2010; 123: 2714-9.

127. Jing P, Qian B, Zhao S, Qi X, Ye L, Giusti MM, et al. Effect of glycosylation patterns of Chinese eggplant anthocyanins and other derivatives on antioxidant effectiveness in human colon cell lines. Food chemistry. 2015; 172: 183-9.

128. Quintos L, Lee I, Kim HJ, Lim J-S, Park J, Sung M-K, et al. Significance of p27kip1 as potential biomarker for intracellular oxidative status. Nutrition research and practice. 2010; 4: 351-5.

129. Yun JM, Afaq F, Khan N, Mukhtar H. Delphinidin, an anthocyanidin in pigmented fruits and vegetables, induces apoptosis and cell cycle arrest in human colon cancer HCT116 cells. Molecular carcinogenesis. 2009; 48: 260-70.

130. Huang W-Y, Liu Y-M, Wang J, Wang X-N, Li C-Y. Anti-inflammatory effect of the blueberry anthocyanins malvidin-3-glucoside and malvidin-3-galactoside in endothelial cells. Molecules. 2014; 19: 12827-41.

131. Katsube N, Iwashita K, Tsushida T, Yamaki K, Kobori M. Induction of apoptosis in cancer cells by bilberry (Vaccinium myrtillus) and the anthocyanins. Journal of agricultural and food chemistry. 2003; 51: 68-75. 